\title{
Effect of Soaking and Fermentation of Wheat Bran on Weight Gain, Accumulative Food Intake and Food Efficiency Ratio in Rats
}

\author{
Hani J. Hamad ${ }^{1}$, Mysaa Ata ${ }^{2}$, Wasfy J. Hamad ${ }^{3}$, \& Hamed R. Takruri ${ }^{4}$ \\ ${ }^{1}$ Department of Food Science and Nutrition, Faculty of Agriculture, Jerash University, Jerash, Jordan \\ ${ }^{2}$ Department of Animal Production, Faculty of Agriculture, Jerash University, Jerash, Jordan \\ ${ }^{3}$ Pulmonary, Critical Care and Respiratory Medicine, Alkhor Hospital, Alkhor, Qatar \\ ${ }^{4}$ Department of Nutrition and Food Technology, Faculty of Agriculture, The University of Jordan, Amman, \\ Jordan \\ Correspondence: Hani J. Hamad, Department of Food Science and Nutrition, Faculty of Agriculture, Jerash \\ University, P.O. Box 311, Jerash 26110, Jordan. Tel: 962-776-190-572. E-mail: hanihamad14@yahoo.com
}

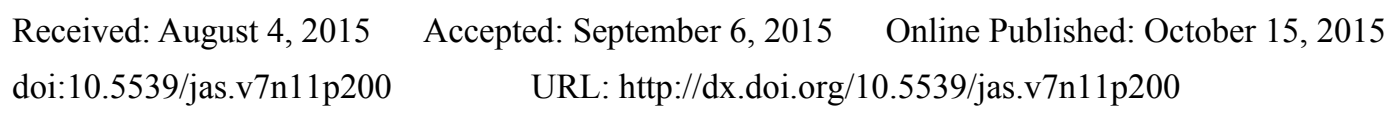

\begin{abstract}
This study was conducted to investigate the effect of different processing treatments in terms of soaking and fermentation of wheat bran on weight gain, accumulative food intake and food efficiency ratio in SpragueDawley rats. The experimental diets included casein diet (zero-bran), untreated bran diet, soaked bran diet, fermented bran diet, "soaked and fermented" bran diet and Arabic bread diet. Each group of rats (6/group) was fed one of the six prepared diets for 6 weeks. There was no significant difference $(p>0.05)$ in the body weight gain among all rat groups, although the rats fed soaked diet tended to have the highest weight gain in comparison with other groups. There was no significant difference in FER among all groups, although, there was a difference between groups in the accumulative food intake. Accumulative food intake (AFI) of the rat group fed soaked bran based-diet was the highest $(685.6 \pm 17.3 \mathrm{gm})$ among all groups whereas AFI of the rat group fed "soaked and fermented" bran-based diet was the lowest (550.0 $\pm 19.1 \mathrm{gm})$. Rat group fed "soaked and fermented" branbased diet had significantly lower levels $(\mathrm{p}<0.05)$ of AFI than those fed untreated bran diet, soaked bran diet and white bread diet $(550.0 \pm 19.1,663.4 \pm 16.6,685.6 \pm 17.3$ and $629.8 \pm 28.4$ gm respectively). Accordingly, the AFI of the rat group fed soaked bran diet was significantly higher $(\mathrm{p}<0.05)$ than those fed casein and fermented diet $(685.6 \pm 17.3,598.4 \pm 9.2$ and $605.8 \pm 25.6$ gm respectively). It is concluded that preparation of wheat bran foods by soaking or/and fermentation improve some physiological characteristics of insoluble fibers, including the body weight changes, accumulative food intake and food efficiency ratio for 6 weeks.
\end{abstract}

Keywords: wheat bran, dietary fiber, soaking, fermentation, weight gain, accumulative food intake, food efficiency ratio, sprague-dawley rat

\section{Introduction}

Carbohydrates, of both insoluble non-starch polysaccharides and soluble NSP, are important contributors to the health benefits of whole grains (Topping, 2007). Dietary fiber is defined as the endogenous components of plant materials in the diet, predominantly non-starch polysaccharides and lignin, which are resistant to digestion by human enzymes (Anderson et al., 1990). Wheat and its products are the major part of the diet for people in many regions of the world, it is second only to rice as the main human food crop (Stevenson et al., 2012; Levrat-Verny et al., 1999).

In Jordan, commercial bread tops the food items that provide dietary fiber with a $38.2 \%$ of the 30.9 gm total dietary fiber per capita per day (Takruri \& Tukan, 1998). Wheat bran is considered a rich source of insoluble fibers, which constitute more than $95 \%$ of extractable fiber (Chen et al., 1998).

It is expected that many factors could alter the physico-chemical properties of dietary fiber (Lopez et al., 1998). Such factors may include soaking and fermentation (Hallberg et al., 1987; Kent \& Evers, 1994). Fermentation of wheat bran was reported to change its physio-chemical properties, by degrading the cell wall material, particularly the aleurone layer rather than lignified outer layer (Stevens et al., 1988). It is locally practiced to add soaked and fermented wheat bran to bread in order to improve loaf characteristics. 
To the best of our knowledge, no study was conducted about the biochemical implications related to weight gain, accumulative food intake and food efficiency ratio as a result of such practice. Therefore, the objective of this work was to investigate the effect of soaking and fermentation of wheat bran on weight gain, accumulative food intake and food efficiency ratio in Sprague-Dawley rats for 6 weeks.

\section{Methods}

\subsection{Sample Preparation}

Hard red winter wheat (Triticum aestivum) bran, obtained from the Modern Flour Mills and Macaroni Factories Co., was used in the study after treatment to get: untreated wheat bran, water-soaked bran, fermented bran and "soaked and fermented" bran. In the soaking process, hot tap water $\left(55^{\circ} \mathrm{C}\right)$ was added to the bran in a ratio of ( $1: 1 \mathrm{w} / \mathrm{v}$ bran to water). Rapid mixing was done for 15 minutes and then the mix was left for 120 minutes to be soaked. The wet bran was spread as a thin layer over aluminum trays $(1-2 \mathrm{~cm}$ thickness) and oven-dried at $\left(82.2^{\circ} \mathrm{C}\right)$ for about 4 hours. The dried bran was milled using a hammer mill. In the fermentation process, hot tap water $\left(55^{\circ} \mathrm{C}\right)$ was added to the bran in a ratio of $(1: 1 \mathrm{w} / \mathrm{v}$ bran to water $)$, and then the yeast was directly added to the mixture (17 $\mathrm{g}$ of fresh baker's yeast paste/kg bran). Rapid mixing was done for 15 minutes and the mixture was left at $38{ }^{\circ} \mathrm{C}$ for 120 minutes to be fermented. The wet fermented bran was spread as a thin layer over an aluminum tray $\left(1-2 \mathrm{~cm}\right.$ thickness) and oven-dried at $82.2{ }^{\circ} \mathrm{C}$ for about 4 hours. The dried bran was milled using a hammer mill. In the "soaking and fermentation" process, bran was also prepared as a mixture of (1part bran: 1 part of hot tap water $\left(55^{\circ} \mathrm{C}\right)$, and mixed rapidly for 15 minutes, then left to be soaked for 120 minutes. After soaking $17 \mathrm{~g}$ of the fresh bakers-yeast paste/kg bran was added and mixed rapidly for 15 minutes and left to be fermented for 120 minutes. The mixture was then oven-dried at $82.2^{\circ} \mathrm{C}$ for about 4 hours. The dried bran was milled using a hammer mill. Arabic bread (white bread) sample was prepared from wheat flour (Triticum aestivum) with an extraction rate between $78-82 \%$, from which the wheat bran was extracted. The other ingredients used in white bread preparation were: sugar (27-30 g/Kg flour), salt (3-5 g/Kg flour), baker's yeast $(10 \mathrm{~g} / \mathrm{Kg}$ flour $)$, and water in a ratio of 2 flour: 1 water. All ingredients were kneaded for 15 minutes in a kneading machine (Bavailler, France). The dough was then transferred to a stainless steel container and left for 20 minutes. This was followed by mechanical cutting into small pieces $(200-220 \mathrm{~g})$, which was fermented on a rotary fermenter for another 20 minutes. After flattening the dough into a thickness of $(0.5-1.0 \mathrm{~cm})$ and a diameter of $(30-35 \mathrm{~cm})$ it was left for another 20 minutes, and then was baked at $350{ }^{\circ} \mathrm{C}$ for 40 seconds. The bread after cooling was dried at $82.2^{\circ} \mathrm{C}$ for about 4 hours and then milled using a hammer mill.

\subsection{Experimental Diets}

Experimental diet mixtures were planned to reach an isocaloric, isonitrogenous content. The casein and corn oil were adjusted according to the protein and fat, respectively, provided by wheat bran. The composition of the mineral and vitamin mixtures was added as given by Reeves (1997). The experimental diets included casein diet (zero-bran) as a control, untreated bran diet (16 gm bran), soaked bran diet (16 gm bran), fermented bran diet (16 gm bran), soaked and fermented bran diet and Arabic bread diet. All diets were kept at $4{ }^{\circ} \mathrm{C}$ until used for feeding. The ingredients of the diets used in the animal experiment are shown in Table 1. 
Table 1. Composition of experimental diets fed to rats ${ }^{(1-4)}$

\begin{tabular}{|c|c|c|c|c|c|c|}
\hline \multirow{2}{*}{ Ingredient (gm/100gm) } & \multicolumn{6}{|c|}{ Type of diet } \\
\hline & Casein & Untreated bran & Soaked bran & Fermented bran & Soaked \& fermented bran & Arabic bread \\
\hline Test food & - & 16 & 16 & 16 & 16 & 70 \\
\hline Casein $^{(1)}$ & 14 & 11.8 & 11.8 & 11.8 & 11.8 & 5.6 \\
\hline Starch & 69.7 & 56.7 & 56.7 & 56.7 & 56.7 & 9.7 \\
\hline Corn oil & 9 & 8.2 & 8.2 & 8.2 & 8.2 & 7.0 \\
\hline Fat-soluble vitamins $^{(2)}$ & 1 & 1 & 1 & 1 & 1 & 1 \\
\hline Water-soluble vitamins ${ }^{(3)}$ & 2 & 2 & 2 & 2 & 2 & 2 \\
\hline Salt mixture ${ }^{(4)}$ & 4 & 4 & 4 & 4 & 4 & 4 \\
\hline DL-methionine & 0.3 & 0.3 & 0.3 & 0.3 & 0.3 & 0.3 \\
\hline Total & 100 & 100 & 100 & 100 & 100 & 100 \\
\hline
\end{tabular}

Note. ${ }^{(1)}$ Casein source: BDH Chemical Ltd. Poole/England; ${ }^{(2)}$ Fat-soluble vitamins mixture: (4000IU vitamin A, $1000 \mathrm{IU}$ vitamin $\mathrm{D}_{2}, 10 \mathrm{IU}$ vitamin $\mathrm{E}$ ) $/ 1 \mathrm{~g}$ fat (Reeves, 1997); ${ }^{(3)}$ Water-soluble vitamin mixture: $0.5 \mathrm{~g}$ thiamin, $0.4 \mathrm{~g}$ riboflavin, $0.4 \mathrm{~g}$ pyridoxine, $45.0 \mathrm{~g}$ ascorbic acid, $4.0 \mathrm{~g}$ pantothenic acid, $4.0 \mathrm{~g}$ niacin. $2.5 \mathrm{~g}$ chloine, $25 \mathrm{mg}$ inositol, $10 \mathrm{mg}$ paraminobenzoic acid. $0.002 \mathrm{~g}$ cyanocobalamine $0.02 \mathrm{~g}$ biotin and $0.2 \mathrm{~g}$ folic acid, made up to 1 $\mathrm{kg}$ with powdered sucrose (Reeves, 1997); ${ }^{(4)}$ Salt mixture: $0.21 \mathrm{~g} \mathrm{Al}_{2}\left(\mathrm{SO}_{4}\right)_{3} \mathrm{~K}_{2} \mathrm{SO}_{4} \cdot 24 \mathrm{H}_{2} \mathrm{O}, 350 \mathrm{~g} \mathrm{CaCO}_{3}, 250 \mathrm{~g}$ $\mathrm{KH}_{2} \mathrm{PO}_{4} \cdot 3 \mathrm{H}_{2} \mathrm{O}, 0.26 \mathrm{~g} \mathrm{CoCl}_{2} \cdot 6 \mathrm{H}_{2} \mathrm{O}, 0.5 \mathrm{~g} \mathrm{CuSO}_{4} \cdot 5 \mathrm{H}_{2} \mathrm{O}, 9.42 \mathrm{~g} \mathrm{Fe}_{2}\left(\mathrm{SO}_{4}\right)_{3} \cdot 7 \mathrm{H}_{2} \mathrm{O}, 102.26 \mathrm{~g} \mathrm{MgSO}_{4} \cdot 7 \mathrm{H}_{2} \mathrm{O}, 1.22 \mathrm{~g}$ $\mathrm{MnSO}_{4} \cdot 4 \mathrm{H}_{2} \mathrm{O}, 0.25 \mathrm{~g} \mathrm{KI}, 135.48 \mathrm{~g} \mathrm{~K}_{2} \mathrm{HPO}_{4} \cdot 3 \mathrm{H}_{2} \mathrm{O}, 127.58 \mathrm{~g} \mathrm{NaCl}, 63.5 \mathrm{mg} \mathrm{NaF}, 81.5 \mathrm{mg} \mathrm{H} \mathrm{BO}_{3}, 3.55 \mathrm{~g}$

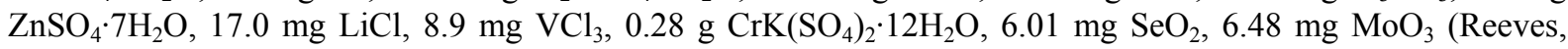
1997).

\subsection{Animal Experimentation}

Thirty six young male adult Albino rats (Sprague-Dawley) were housed individually in plastic cages with wire bottom (North Kent Plastic Cages, England), in an animal room with a 12-hour light: dark cycle at a temperature of $22 \pm 1{ }^{\circ} \mathrm{C}$. All animals had free access to tap water and special diets (given ad libitum). The animals were randomly divided into six groups of six animals each according to body weights. The difference in mean weight between any two groups did not exceed $1 \mathrm{gm}$. Each group of rats was fed one of the six prepared diets for 6 weeks.

\subsection{Proximate Analysis}

Moisture, ash, crude protein, crude fat and crude fiber contents, of bran and bran-based diets, where determined according to AOAC methods (1995). Nitrogen free extract, which represents soluble carbohydrates, was calculated in the sample by difference after subtraction of the crude protein, crude fat, crude fiber, moisture, and ash contents from $100 \%$.

\subsubsection{Weight Gain}

Weight gain (final weight - initial weight) in rats at the end of the experimental period (6 weeks) is used as an indicator for growth and the performance of the different experimental treatments.

\subsubsection{Food Efficiency Ratio (FER)}

Food efficiency ratio (FER) was calculated from the weight gain and accumulative food intake data at the end of 6 weeks for the six groups as follows:

$$
\text { FER }=\text { Gain in body weight }(\mathrm{gm}) / \text { food intake }(\mathrm{gm}) \times 100 \%
$$

\subsection{Statistical Analysis}

Statistical analysis of data was performed using SAS (Statistical Analysis System) package. Analysis of variance (ANOVA) with Duncan's Multiple Range Test (Steel \& Torrie, 1980), was used to find the differences among mean values of the following parameters: body weight changes, accumulative food intake and food efficiency ratio. Significance was accepted at $(\mathrm{p}<0.05)$. 


\section{Results}

The proximate analysis of the bran and other prepared foods, used to formulate the experimental diets, is presented in Table 2. The percentage composition of crude protein is around $14 \%$ for all bran foods while it was lower in Arabic bread (12.4\%). Fat percentage ranged from 4.5 to 5.1 in the bran foods, while it was $2.8 \%$ for white bread. For crude fiber, untreated bran contained 9.8\% (on air-dried basis) while it was lower in other processed bran (soaked 5.6\%, fermented 7\%, and "soaked and fermented" $6.1 \%$ ). Bread had lower percentage of crude fiber $(0.5 \%)$. The proximate analysis of experimental diets, fed to rats for 6 weeks, is presented in Table 3 . The results show that all experimental diets tended to be isocaloric and contained similar amounts of protein, fat and carbohydrate (NFE).

Table 2. Proximate analysis of wheat bran and other ingredients used in preparing the experimental diets ${ }^{(1-3)}$

\begin{tabular}{llllllll}
\hline Composition gm/100gm food & & Protein & Fat & N.F.E. & Ash & Crude fiber & Total \\
\hline Untreated bran & 12.1 & 14.1 & 4.8 & 54.9 & 4.3 & 9.8 & 100 \\
Soaked bran & 7.3 & 14.4 & 5.1 & 64.2 & 3.4 & 5.6 & 100 \\
Fermented bran & 7.7 & 14.7 & 4.7 & 62.0 & 3.9 & 7 & 100 \\
Soaked and fermented bran & 8.1 & 13.8 & 4.5 & 63.3 & 4.2 & 6.1 & 100 \\
Arabic bread & 11.0 & 12.4 & 2.8 & 71.8 & 1.5 & 0.5 & 100
\end{tabular}

Note. ${ }^{(1)}$ Mean values of triplicates with C.V. $<5 \%$ on air-dried samples; ${ }^{(2)}$ Protein was calculated as (Nx6.3) and (Nx5.7) for bran and white bread respectively (Pellett and Young, 1980); ${ }^{(3)}$ NFE: Nitrogen-free extract was calculated by subtraction of moisture, ash, protein, fat and crude fiber from $100 \%$.

Table 3. Proximate analysis of experimental diets ${ }^{(1-3)}$

\begin{tabular}{lllllll}
\hline $\begin{array}{l}\text { Composition } \\
\text { gm/100 gm food }\end{array}$ & Casein & Untreated & Soaked & Fermented & Soaked and fermented & Arabic bread \\
\cline { 1 - 4 } Moisture & 5.2 & 6.0 & 3.7 & 3.3 & 2.8 & 2.8 \\
Protein & 14.2 & 13.8 & 13.9 & 14.3 & 14.0 & 15.2 \\
Fat & 10.6 & 9.4 & 10.7 & 10.4 & 9.6 & 9.9 \\
N.F.E & 65.9 & 66.5 & 66.6 & 66.8 & 68.0 & 67.0 \\
Ash & 4.1 & 4.0 & 4.2 & 4.2 & 4.6 & 5.1 \\
Crude fiber & $\mathrm{ND}$ & 1.4 & 0.9 & 1.0 & 1.0 & ND \\
Energy & 416 & 405 & 418 & 418 & 415 & 418
\end{tabular}

Note. ${ }^{(1)}$ Mean values of triplicates with C.V. $<5 \%$ on air-dried samples; ${ }^{(2)}$ N.F.E.: Nitrogen-free extract was calculated by subtraction of moisture, ash, protein, fat and crude fiber from $100 \% ;{ }^{(3)} \mathrm{ND}$ means not detected.

\subsection{Body Weight Gain}

The body weight gain for rats fed the seven experimental diets for 6 weeks is presented in Table 4. Mean \pm SD values of weight gain for rats fed casein diet, untreated bran diet, soaked bran diet, fermented bran diet, soaked and fermented bran diet and Arabic bread diet were $97.4 \pm 17.9,91.0 \pm 14.2,118.1 \pm 26.1,100.2 \pm 22.6,99.0 \pm$ 18.6 and $93.3 \pm 10.0 \mathrm{gm}$, respectively. There was no significant difference $(\mathrm{p}>0.05)$ in the body weight gain among all rat groups, although the rats fed soaked diet tended to have the highest weight gain in comparison with other groups. 
Table 4. Initial and final body weights and weight gain of rats fed the experimental diets for 6 weeks ${ }^{(1-2)}$

\begin{tabular}{llll}
\hline Type of diet & Initial body weight $(\mathrm{g})$ & Final body weight $(\mathrm{g})$ & Weight gain $(\mathrm{g})$ \\
\hline Casein & $178.4^{\mathrm{a}} \pm 20.65$ & $275.8^{\mathrm{a}} \pm 26.24$ & $97.4^{\mathrm{a}} \pm 17.87$ \\
Untreated & $178.6^{\mathrm{a}} \pm 7.68$ & $269.6^{\mathrm{a}} \pm 27.40$ & $91.0^{\mathrm{a}} \pm 14.15$ \\
Soaked & $178.8^{\mathrm{a}} \pm 11.98$ & $296.9^{\mathrm{a}} \pm 32.01$ & $118.1^{\mathrm{a}} \pm 26.08$ \\
Fermented & $178.5^{\mathrm{a}} \pm 18.66$ & $278.7^{\mathrm{a}} \pm 35.36$ & $100.2^{\mathrm{a}} \pm 22.62$ \\
Soaked and fermented & $178.7^{\mathrm{a}} \pm 9.82$ & $277.7^{\mathrm{a}} \pm 9.25$ & $99.0^{\mathrm{a}} \pm 18.62$ \\
White bread & $178.4^{\mathrm{a}} \pm 12.87$ & $271.7^{\mathrm{a}} \pm 19.25$ & $93.3^{\mathrm{a}} \pm 10.02$
\end{tabular}

Note. ${ }^{(1)}$ Mean of 6 rats $\pm \mathrm{SD} ;{ }^{(2)}$ Means with similar letters in their superscript within the same column are not significantly different $(\mathrm{p}>0.05)$.

\subsection{Accumulative Food Intake and Food Efficiency Ratio}

Table (5) shows the accumulative food intake (AFI) and food efficiency ratio (FER) of rats fed the six experimental diets for 6 weeks. Mean \pm SD values of the food efficiency ratio of rats fed casein diet, untreated bran diet, soaked bran diet, fermented bran diet, soaked and fermented bran diet, and white bread diet were 16.2 $\pm 1.8,13.5 \pm 1.6,17.2 \pm 2.5,16.2 \pm 0.7,18.1 \pm 2.4$ and $14.5 \pm 2.4 \mathrm{gm}$, respectively. There was no significant difference in FER among all groups, although, there was a difference between groups in the accumulative food intake. Accumulative food intake of the rat group fed soaked bran based-diet was the highest among all groups whereas AFI of the rat group fed "soaked and fermented" bran-based diet was the lowest. Rat group fed "soaked and fermented" bran-based diet had significantly lower levels $(\mathrm{p}<0.05)$ of AFI than those fed untreated bran diet, soaked bran diet and white bread diet. Accordingly, the AFI of the rat group fed soaked bran diet was significantly higher $(p<0.05)$ than those fed casein and fermented diet.

Table 5. Accumulative food intake and food efficiency ratio of rats fed the experimental diets for 6 weeks ${ }^{(1-3)}$

\begin{tabular}{lll}
\hline Type of diet & Accumulative food intake & Food efficiency ratio \\
\hline Casein & $598.4^{\mathrm{bc}} \pm 9.2$ & $16.2^{\mathrm{a}} \pm 1.8$ \\
Untreated & $663.4^{\mathrm{ab}} \pm 16.6$ & $13.5^{\mathrm{a}} \pm 1.6$ \\
Soaked & $685.6^{\mathrm{a}} \pm 17.3$ & $17.2^{\mathrm{a}} \pm 2.5$ \\
Fermented & $605.8^{\mathrm{bc}} \pm 25.6$ & $16.2^{\mathrm{a}} \pm 0.7$ \\
Soaked and fermented & $550.0^{\mathrm{c}} \pm 19.1$ & $18.1^{\mathrm{a}} \pm 2.4$ \\
White bread & $629.8^{\mathrm{ab}} \pm 28.4$ & $14.5^{\mathrm{a}} \pm 2.4$
\end{tabular}

Note. ${ }^{(1)}$ Mean of 6 rats $+\mathrm{SD} ;{ }^{(2)}$ Food efficiency ratio: grams of body weight gain per 100 gm of diet consumed $\times 100 \%$; ${ }^{(3)}$ Means with different letters in their superscript within the same column are significantly different $(\mathrm{p}$ $<0.05)$.

\section{Discussion}

This study aimed mainly at identifying the extent to which the processing of wheat bran could alter its effect on on weight gain, accumulative food intake and food efficiency ratio in Sprague-Dawley rats, in comparison with fiber-free diet (casein diet).

Results obtained from this study regarding the proximate analysis were generally in agreement with those reported in the literature. The protein content for wheat bran tended to be similar to that reported by Pomeranz (1988), Holland et al. (1990), and Takruri (2002); while it was slightly higher than what was reported by Kent and Evers (1994), and Williams (1997). The protein content of white wheat bread was similar to that reported by Pellet and Shadarevian (1970), and Takruri (2002). The fat content in bran was similar to that reported by Holland et al. (1990), Williams (1997), and Takruri (2002), while it was higher than values obtained by Pomeranz (1988), and Kent and Evers (1994). The fat content of white Arabic bread was similar to that reported by Pellett and Shadarevian (1970), and Takruri (2002). For crude fiber, untreated bran had similar content of that reported by Kent and Evers (1994), and Takruri (2002). However, processed brans (soaked, fermented and 
"soaked and fermented") had lower percentages of crude fiber than that corresponding to untreated bran.

The variations in protein and fat content of different sources, were expected and could be attributed to the differences in wheat variety from which bran and bread flours were extracted or to the origin of wheat regarding geographical and climate conditions. As indicated by Takruri (2002), the variations also may be due to the presence of varying starch endosperm fractions in the bran which, accordingly, can also contribute to such slight differences in the composition.

Differences in crude fiber content among different prepared bran foods may be due to the effect of soaking, fermentation or "soaking and fermentation" processes on the chemical properties of the bran fibers. This is in agreement with Amaral-Collaco (1998) who found a reduction of both hemicellulosic and cellulosic fractions in tomato pomace when it was fermented with a mixed culture of Trichoderma reesei and Chrysoporium pruinosum.

Wang et al. (1993) found that insoluble dietary fiber was lower in wheat bran than in the raw sample suggesting that the decreased insoluble dietary fiber and increased soluble dietary fiber in extruded products could be the result of disruption of covalent and covalent bonds in the carbohydrate and protein moieties, leading to smaller and more soluble molecular fragments. This was consistent with the data obtained by Lena et al. (1997) who found increased soluble DF content of wheat bran by enzymatic treatment.

The proximate composition of experimental diets used in the feeding of experimental rats were made similar in order to exclude any confounding factors other than intended ones. The results show that all experimental diets are isocaloric, and provide practically equal amounts of protein, fat and other constituents, which is needed for ruling out of any metabolic changes resulting from energy content.

Body weight gain can be used as an indicator of nutrient utilization and bioavailability (Moeljopawiro et al, 1988). The results of the present study demonstrate no significant changes in body weight gain of rats fed the different treated and untreated bran diets compared to the casein and white wheat bread diets. These results are consistent with those reported by Nishina et al. (1991), Ahmad and Takruri (1991) and Anderson et al. (1994), who found that the weight gains, in rats, were similar or not significantly different for rats fed the basal diet or wheat bran diet. A strong relationship between dietary fiber and, weight gain has been reported in one of the recent study, where Sáyago-Ayerdi et al. (2014) found that weight gain in the Agave tequilana dietary fibre and jamaica calyces (ADF-JC) group, after consuming the test diets for 5 weeks, was significantly lower than in the other groups.

These results are also in agreement with the results obtained by Takruri (2002) who used similar bran treatments obtained from the same source; there was a lack of significancy among different test diets regarding weight gain data. However, there was a trend in present results for the increment in body weight gain for the processed or treated bran diets. This trend could be explained by the notice that untreated bran diet resulted in an obvious bulky feces in comparison with other test diets. It could be suggested that more processed wheat fiber decreases fecal output as compared with raw and unprocessed wheat bran fiber. This suggestion is consistent with that of Vuksan et al. (1999). These authors stated that processed wheat fiber produces a reduction in the amount of phytate, in addition to affecting fecal bulkiness as well as the transit time. Moreover, a study performed by Takruri and Hamad in 2005 to investigate the effect of different processing treatments in terms of soaking and fermentation of wheat bran on serum lipids and lipoproteins in Sprague-Dawley rats. The authors found that preparation of wheat bran foods by soaking or/and fermentation improved some physiological characteristics of insoluble fibers, including the cholesterol-lowering ability (particularly total cholesterol TC and low-density lipoprotein cholesterol LDL-C).

Accumulative food intake is an indicator for the palatability of the diet and the acceptability of animals for the diets. There was no significant difference in FER among all groups, although, there was a difference between groups in the accumulative food intake. These findings, regarding FER are in close agreement with the findings of Takruri (2002) who used similar bran treatments. Accumulative food intake values varied among the experimental diets although there was no significant difference in FER. This could be attributed to the adaptation and to a compensatory increase in food intake, which in turn works to maintain body weight gain to be constant, since, the FER depends on weight gain. Maybe if the experiment prolongs to more than 6 weeks, the results will give better picture about this effect. As shown in Table 5, soaked bran diet resulted in the highest and significant food intake among all test diets, including casein. This could be explained by the increased palatability of soaked bran as a result of soaking process in comparison with other treatments. Little information is known about the effect of soaking, fermentation and "soaking and fermentation" methods because of the scarcity of studies dealing with the effects of such methods on weight gain, accumulative food intake and food efficiency ratio in 
Sprague-Dawley rats. In other studies, fermentation had resulted in a reduction of both hemicellulosic and cellulosic fraction, which may behave as a soluble fraction and as a result this could be effective in altering weight gain, accumulative food intake and food efficiency ratio (Amaral-Collaco, 1998). Other processes, like extrusion cooking have been reported to increase the soluble fiber content of wheat bran and other food by-products rich in insoluble dietary fiber.

\section{Conclusion}

The soaking, fermentation, and "soaking and fermentation" processes of wheat bran results in a favorable effect on accumulative food intake in Sprague-Dawley rats through affecting the physicochemical properties of wheat bran rendering insoluble fraction of fiber behave like a soluble one. Although there was no significant effect of soaking, fermentation and "soaking and fermentation" methods on weight gain and food efficiency ratio at this study, it seems possible that these treatments slightly affect rats performance. Therefore, further investigation is required to support our findings.

\section{Acknowledgements}

The authors would like to thank Deanship of Academic Research at The University of Jordan and Al-Sufara Bakeries for the financial support.

\section{References}

Ahmad, M. N., \& Takruri, H. R. (1991). Effects of dietary wheat bran on serum glucose, body weight, food intake and food efficiency in rats. Mu'tah J. Res. Stud., 6(1), 53-16.

Amaral-Collaco, M. T. (1998). The Effects of processing on dietary fibers from agroindustrial residues. In F. Guillon, R. Amado, M. T. Amaral-Collaco, H. Anderson, N. G. Asp, K. E. Bach Knudsen, ... J. Vanloo (Eds.), Functional Properties of Non-digestible Carbohydrates. Published by Imprimerie Parantheses Nantes, France.

Anderson, J. W., Deakins, D. A., Floore, T. L., Smith, B. M., \& Whitis, S. E. (1990). Dietary fiber and coronary heart disease. Crit. Rev. Food Sci. Nutr., 29(2), 95-147. http://dx.doi.org/10.1080/10408399009527518

Anderson, J. W., Jones, A. E., \& Riddell-Mason, S. (1994). Ten different dietary fibers have significantly different effects on serum and liver lipids of cholesterol-fed rats. J. Nutr., 124, 78-83.

AOAC. (1995). Official Methods of Analysis of the Association of Official Analytical Chemists (16th ed.). Association of Official Analytical Chemists, Virginia, USA.

Chen, H. L., Haack, V. S., Janecky, C. W., Vollendorf, N. W., \& Marlett, J. A. (1998). Mechanisms by which wheat bran and oat bran increase stool weight in humans. Am. J. Clin. Nutr., 68, 711-9.

Hallberg, L., Rossander, L., \& Skanberg, A. (1987). Phytates and the inhibitory effect of bran on iron absorption in man. Am. J. Clin. Nutr., 45, 988-96.

Holland, B., Welch, A. A., Unwin, I. D., Buss, D. H., Paul, A. A., \& Southgate, D. A. T. (1990). McCance and Widdowson's: The Compostion of Foods (4th ed.). The Royal Society of chemistry and MAFF, Cambridge.

Kent, N. L., \& Evers, A. D. (1994). Technology of Cereals (4th ed.). Elsvier Science Ltd. UK.

Lena, G. D., Patroni, E., \& Quaglia, G. B. (1997). Improving the nutritional value of wheat bran by a white-rot fungus. Intern. J. Food Sci. Tech., 32, 513-519. http://dx.doi.org/10.1111/j.1365-2621.1997.tb02125.x

Levrat-Verny, M. A., Coudary, C., Bellanger, J., Lopez, H., Demigne, C., Rayssiguier, Y., \& Remesy, C. (1999). Whole-wheat flour ensures higher mineral absorption and bioavailability than white wheat flour in rats. $\mathrm{Br}$. J. Nutr., 82, 17-21. http://dx.doi.org/10.1017/S0007114599001075

Lopes-Virella, M. F., Stone, P., Ellis, S., \& Colwell, J. A. (1977). Cholesterol determination in high-density lipoproteins separated by three different method. Clin. Chem., 23(5), 882-884.

Lopez, H. W., Coudary, C., Bellanger, J., Younes, H., Demigne, C., \& Remesy, C. (1998). Intestinal fermentation lessens the inhibitory effects of phytic acid on mineral utilization in rats. J. Nutr., 128, 1192-98.

MoeljoPawiro, S., Fields, M. L., \& Gordaon, D. (1988). Bioavailability of zinc in fermented soybeans. J. Food Sci., 53, 460-463. http://dx.doi.org/10.1111/j.1365-2621.1988.tb07730.x

Nishina, P. M., Schneeman, B. O., \& Freedland, R. A. (1991). Effects of dietary fibers on nonfasting plasma lipoprotein and apolipoprotein levels in rats. J. Nutr., 121, 431-437. 
Pellett, P. L., \& Shaderevian, S. (1970). Food Composition Table for Use in the Middle East. American University of Beirut, Beirut, Lebanon.

Pomeranz, Y. (1988). Chemical composition kernel structure. In Y. Pomeranz (Ed.), Wheat: Chemistry and Technology (Vol. I). American Association of Cereal Chemists, Inc. St Paul, Minnesota, USA.

Reeves, P. G. (1997). Components of the AIN-93 diets as improvements in the AIN-76A diet. J. Nutr., 127, 838S-841S.

Sáyago-Ayerdi, S. G., Mateos, R., Ortiz-Basurto, R. I., Largo, C., Serrano, J., Granado-Serrano, A. B., ... Tabernero, M. (2014). Effects of consuming diets containing Agave tequilana dietary fibre and Jamaica calyces on body weight gain and redox status in hypercholesterolemic rats. Food Chemistry, 148, 54-59. http://dx.doi.org/10.1016/j.foodchem.2013.10.004

Steel, R. G. D., \& Torrie, J. H. (1980). Principles and Procedures of Statistics a Biometrical Approach (2nd ed.). McGraw-Hill, Inc. Tokyo.

Stevens, B. J. H., Selvendran, R. R., Bayliss, C. E., \& Turner, R. (1988). Degradation of cell wall material of apple and wheat bran by human faecal bacteria in vitro. J. Sci. Food Agric., 44, 151-166. http://dx.doi.org/10.1002/jsfa.2740440207

Stevenson, L., Phillips, F., O'sullivan, K., \& Walton, J. (2012). Wheat bran: Its composition and benefits to health, a European perspective. Int $J$ Food Sci Nutr, 63(8), 1001-1013. http://dx.doi.org/10.3109/09637486.2012.687366

Takruri, H. R., \& Hamad, H. J. (2005). The effect of different processing treatments of wheat bran on serum lipids and lipoproteins in Sprague-Dawley rat. Arab J Food Nutr, 6(12), 6-16.

Takruri, H. R., \& Tukan, S. K. (1998). Dietary fiber in Jordanian diet. Intern. J. Food Sci. Nutr., 49, S47-S52.

Takruri, W. (2002). The effect of in-vitro soaking and fermentation of wheat bran on bioavailability of calcium, zinc, iron, and magnesium (Master Thesis, University of Jordan, Jordan).

Topping, D. (2007). Cereal complex carbohydrates and their contribution to human health. J Cereal Sci, 46, 220-229. http://dx.doi.org/10.1016/j.jcs.2007.06.004

Vuksan, V., Jenkins, D. J. A., Vidgen, E., Ransom, T. P. P., Ng, M. K., Culhane, C. T., \& O’Connor, D. (1999). A novel source of wheat fiber and protein: effects on fecal bulk and serum lipids. Am. J. Clin. Nutr., 69, 226-30.

Wang, W. M., Klopfenstein, C. F., \& Ponte, J. G. (1993). Effects of twin-screw extrusion on the physical properties of dietary fiber and other components of whole wheat and wheat bran and on the baking quality of the wheat bran. Cereal Chem., 70(6), 707-711.

Williams, S. R. (1997). Nutrition and Diet Therapy (8th ed.). Mosby, St. Louis.

\section{Copyrights}

Copyright for this article is retained by the author(s), with first publication rights granted to the journal.

This is an open-access article distributed under the terms and conditions of the Creative Commons Attribution license (http://creativecommons.org/licenses/by/3.0/). 